\title{
Characteristics of infertility in female hypothyroid (hyt) mice
}

\author{
J. Y. Jiang, Y. Imai, M. Umezu and E. Sato \\ Laboratory of Animal Reproduction, Graduate School of Agricultural Science, Tohoku \\ University, Sendai 981-8555, Japan
}

Female hypothyroid (hyt) mice are infertile, but the reason for this infertility is not yet known. The present study was conducted to determine whether hypothyroidism induced infertility in immature and mature hyt mice. Furthermore, animals were treated with thyroxine and gonadotrophins at different times to determine whether infertility was due to failure of follicular development, implantation or pregnancy. There were no significant differences in the numbers of ovulated eggs induced by gonadotrophin treatment or the percentages of eggs developed in vitro among immature normal controls, hyt and thyroxinetreated hyt mice. Mature hyt mice showed continuous dioestrus, and ovulated significantly fewer eggs after gonadotrophin treatment and failed to establish pregnancy after mating compared with mature control mice. Mature hyt mice had significantly fewer corpora lutea $>500 \mu \mathrm{m}$ in diameter and significantly lower progesterone concentrations. Thyroxine treatment before mating in hyt mice resulted in well-developed corpora lutea, an increase in progesterone and normal pregnancy, regardless of subsequent thyroxine administration. In conclusion, infertility occurs in mature rather than immature hyt mice, is due to the failure of follicular development and pregnancy, and can be reversed by thyroxine treatment before mating.

\section{Introduction}

The hyt mouse has an autosomal recessive, fetal onset, severe hypothyroidism that persists throughout life. The defective thyroid stimulating hormone (TSH) receptor and thyroidal agenesis make the hyt/hyt mouse a good model for this same condition in humans (Stein et al., 1994; Biesiada et al., 1996). hyt mice have been used to study the effects of thyroid hormones on the development and functions of many organs, including the brain (Sher et al., 1998; Khan et al., 1999), lung (Ansari et al., 1997, 2000), kidney (Sole et al., 1994, 1996) and male reproductive organs (Amador et al., 1986; Kuroda, 1989). hyt mice of both sexes have been reported to be infertile but the infertility of males can be reversed by supplementing their feed with desiccated thyroid powder (Beamer et al., 1981). In contrast, other studies have indicated that male hyt mice are fertile (Chubb and Nolan, 1985; Chubb and Henry, 1988). Although female hyt mice were described as infertile by Beamer et al. (1981), data to support this conclusion were not included in this study. Therefore, the aim of the present study was to investigate whether and to what extent female hyt mice are infertile in both immature and mature stages.

\section{Materials and Methods}

\section{Preparation of animals}

hyt mice were produced by mating adult C.RF-Tshr hyt/+ males with females purchased from the Jackson Laboratory

Email: jiang@bios.tohoku.ac.jp
(Bar Harbor, ME). In the present study, the term hyt mice always refers to hyt/hyt homozygotes, while normal littermates include both $h y t /+$ and wild types $(+/+)$ since there are no phenotypic differences between them. Animals were placed in polycarbonate cages $(30 \mathrm{~cm} \times 20 \mathrm{~cm} \times$ $13 \mathrm{~cm}$ ) with wood shavings on the floor in a room at a controlled temperature of $24 \pm 2^{\circ} \mathrm{C}$ and humidity of $65 \pm 5 \%$ with lights coming on at 7:00 $\mathrm{h}$ and going off at 19:00 h. Mice were given pelleted commercial food (MEQ: Oriental Yeast Co. Ltd, Chiba) and tap water ad libitum. hyt mice were distinguished according to their low body weight and retarded ear development at about 2 weeks of age (Adams et al., 1989).

The present study was approved by the Ethics Committee for Care and Use of Laboratory Animals for Biomedical Research of the Graduate School of Agricultural Science, Tohoku University.

\section{Fertility in immature hyt mice}

Hormone administration. Immature hyt mice and their normal littermates were divided randomly and treated as follows to examine the roles of gonadotrophins and thyroid hormones in ovulation in hyt mice: (i) gonadotrophins (eCG and hCG) alone in both hyt and normal mice; and (ii) thyroxine combined with gonadotrophins in hyt mice alone. hyt mice were administered thyroxine (L-thyroxine, Sigma Chemical Co., St Louis, MO) i.p. once a day at a dose of $10 \mu \mathrm{g}$ per $100 \mathrm{~g}$ body weight from days 21 to 30 of age. Thyroxine was dissolved in $2 \mathrm{~mol} \mathrm{NaOH} \mathrm{I}^{-1}$ and prepared in physiological saline solution (final $\mathrm{pH}$ 7.0). In both hyt and normal mice, 5 iu eCG (Sankyo Kabu 
Company, Tokyo) was injected i.p. at 18:00 h on day 28 and 5 iu hCG (Sankyo Kabu Company) was administered i.p. $48 \mathrm{~h}$ later.

Egg collection and examination of fertilization. After hCG injection, all female mice were paired with mature hyt males, which were treated with thyroxine from days 21 to 40 of age by injection as described in previous studies on immature $r d w$ rats (Jiang et al., 1999, 2000a) and were subsequently given drinking water supplemented with thyroxine (Jiang et al., 2000b). The next morning, the animals were killed by cervical dislocation and eggs were collected by flushing oviducts with culture medium as described by Jiang et al. (1999). The culture medium was CZB (Chatot et al., 1989; Wakayama et al., 1998) supplemented with $5.56 \mathrm{mmol}$ D-glucose $\mathrm{I}^{-1}$ (Wako Pure Chemical Industries Ltd, Osaka) and $5 \mathrm{mg} \mathrm{BSA} \mathrm{ml}^{-1}$ (No. A7638, Fraction V, Sigma). The eggs were counted, and only those eggs with two distinct pronuclei and a second polar body (Wakayama et al., 1998) were considered to be fertilized and were included in the analysis.

Embryo culture in vitro. Embryo culture and examination of development were conducted as described by Wakayama et al. (1998) and Jiang et al. (1999). Briefly, after washing three to six times with culture medium, approximately ten fertilized eggs were transferred to $100 \mu \mathrm{l}$ of culture medium and cultured in a $\mathrm{CO}_{2}$ incubator at $37^{\circ} \mathrm{C}, 5 \% \mathrm{CO}_{2}$ in air, for 5 days. Embryo development was examined every $24 \mathrm{~h}$.

\section{Fertility in mature hyt mice}

Hormone administration. Eight-week-old hyt mice were divided into five groups and treated as follows to examine the characteristics of infertility and the effects of thyroxine treatment: (i) given no hormone treatment; (ii) given gonadotrophin (eCG and hCG) treatment alone; (iii) given gonadotrophin treatment with thyroxine after mating; (iv) given thyroxine before mating (from day 21 of age to the day of mating) alone; and ( $\mathrm{v}$ ) given thyroxine treatment before and after mating (from day 21 of age to the day of examination) alone. Normal littermates with gonadotrophin treatment alone were used as controls. Thyroxine was administered by i.p. injection each day from days 21 to 40 of age as described above and subsequently in drinking water supplemented with thyroxine solution at a final concentration of $3 \mu \mathrm{g} \mathrm{ml}^{-1}$ as described by jiang et al. (2000b). The stage of the oestrous cycle was evaluated each day by smear examination. eCG (5 iu) was injected i.p. at 18:00 h on day 58 of age and 5 iu hCG was administered i.p. $48 \mathrm{~h}$ later. Each female mouse in pro-oestrus or after hCG injection was paired with a male hyt mouse treated with thyroxine as described above.

Egg collection and ovary sampling. All female mice were checked for vaginal plugs the morning after pairing with males. Animals in corresponding groups were killed by cervical dislocation and eggs were collected from the oviducts by flushing with CZB medium. Ovaries $(n=3)$ in corresponding groups were collected for histological examination, performed as described by Jiang et al. (2000a). Briefly, ovaries were fixed in neutral buffered formalin solution, embedded in paraffin wax, sectioned at a thickness of $8 \mu \mathrm{m}$ and stained with haematoxylin-eosin. Healthy and atretic follicles were examined according to the criteria of Hirshfield and Midgley (1978) and Braw and Tsafriri (1980).

Implantation and pregnancy. Female hyt mice with vaginal plugs in corresponding groups were kept to examine whether normal implantation and pregnancy occurred. Animals were checked once a day by smear examination. Females that showed pro-oestrous smears, or that were pregnant but did not deliver offspring by day 24 of pregnancy, were killed and their uterine horns were examined for implantation sites.

Blood sampling and examination of corpus luteum formation. Four days after mating, females in corresponding groups were anaesthetized after their body weight had been measured. Blood was collected from the heart, and serum was immediately separated by centrifugation at $900 \mathbf{g}$ for $15 \mathrm{~min}$ at $4^{\circ} \mathrm{C}$ and stored at $-20^{\circ} \mathrm{C}$ until examination (Umezu et al., 1998; Jiang et al., 2000a,b). Ovaries were collected and examined for corpora lutea histologically using haematoxylin-eosin staining.

Progesterone assay. Progesterone concentrations were measured using a kit (DELFIA-Progesterone Reagents R066101), according to the manufacturer's instructions (Pharmacia Biotech KK, Tokyo). The limit of sensitivity of the assay was $0.25 \mathrm{ng} \mathrm{ml}^{-1}$. The interassay and intra-assay variations were 8.1 and $4.2 \%$, respectively. Data are shown as means \pm SEM $(n=5)$.

\section{Statistical analysis}

Student's $t$ test was used to compare differences in the number of corpora lutea in mature hyt mice given gonadotrophins alone and those given thyroxine alone. ANOVA and Duncan's multiple-range test were used for other comparisons. Differences were considered significant at $P<0.05$.

\section{Results}

Immature hyt mice given a single injection of eCG and hCG on days 28 and 30 of age, respectively, ovulated as many eggs as did normal controls on day 31 of age. Pre-treatment with thyroxine did not affect ovulation in immature hyt mice. Fertilization rates were not significantly different among hyt mice, hyt mice given thyroxine and normal controls (Table 1).

There were no significant differences in the development in vitro of eggs derived from hyt mice, hyt mice given thyroxine and normal controls (Table 2). 
Table 1. Ovulation and fertilization in immature hypothyroid mice (hyt) and normal littermates (normal) given gonadotrophins alone, and in hyt mice given thyroxine and gonadotrophins (T4-hyt)

\begin{tabular}{|c|c|c|c|c|}
\hline \multirow[b]{2}{*}{ Females } & \multirow{2}{*}{$\begin{array}{l}\text { Number of mice } \\
\text { ovulating/tested }\end{array}$} & \multicolumn{2}{|c|}{ Number of eggs collected } & \multirow{2}{*}{$\begin{array}{l}\text { Number }(\%)^{*} \text { of } \\
\text { eggs fertilized }\end{array}$} \\
\hline & & Total & Mean \pm SEM & \\
\hline hyt & $7 / 7$ & 123 & $17.6 \pm 2.9$ & $101(82.1)$ \\
\hline T4-hyt & $6 / 6$ & 115 & $19.2 \pm 1.9$ & $101(87.8)$ \\
\hline Normal & $22 / 22$ & 377 & $17.1 \pm 1.1$ & $336(89.1)$ \\
\hline
\end{tabular}

*Percentage of the number of eggs collected.

After injection with hCG, all females were paired with mature male hyt mice treated with thyroxine from 21 days of age.

Table 2. Development in vitro of eggs derived from immature hypothyroid mice (hyt) and normal littermates (normal) given gonadotrophins alone, and in hyt mice given thyroxine and gonadotrophins (T4-hyt)

\begin{tabular}{|c|c|c|c|c|c|}
\hline \multirow[b]{2}{*}{ Females } & \multirow[b]{2}{*}{ Number of eggs cultured } & \multicolumn{4}{|c|}{ Number $(\%)^{*}$ of eggs developed to } \\
\hline & & $\geqslant$ Two-cell $(48)^{\dagger}$ & $\geqslant$ Four-cell $(72)^{+}$ & $\geqslant$Morula $(96)^{+}$ & Blastocyst $(120)^{+}$ \\
\hline hyt & 75 & $75(100)$ & $66(88.0)$ & $57(76.0)$ & $37(49.3)$ \\
\hline T4-hyt & 79 & $79(100)$ & $67(84.4)$ & $58(73.4)$ & $44(55.7)$ \\
\hline Normal & 216 & $216(100)$ & $185(85.6)$ & $134(62.0)$ & $106(49.1)$ \\
\hline
\end{tabular}

*Percentage of the number of eggs cultured.

${ }^{+}$Numbers in parentheses indicate time ( $h$ ) after hCG injection.

After hCG injection, all females were paired with mature male hyt mice treated with thyroxine from 21 days of age.

Table 3. Ovulation in mature hypothyroid (hyt) mice with or without treatment with gonadotrophins

\begin{tabular}{|c|c|c|c|c|c|}
\hline \multirow[b]{2}{*}{ Females } & \multirow{2}{*}{$\begin{array}{l}\text { Gonadotrophins } \\
\text { (eCG and hCG) }\end{array}$} & \multicolumn{3}{|c|}{ Number of mice } & \multirow{2}{*}{$\begin{array}{c}\text { Number of eggs } \\
\text { collected per mouse }\end{array}$} \\
\hline & & Tested & Oestrus & Ovulation & \\
\hline hyt & - & 5 & 0 & 0 & $0^{\mathrm{a}}$ \\
\hline hyt & + & 6 & ND & ND & $9.8 \pm 1.3^{b}$ \\
\hline Normal & + & 5 & 5 & 5 & $20.8 \pm 1.7^{c}$ \\
\hline
\end{tabular}

Oestrus: number of animals showing oestrus; ovulation: number of animals ovulating eggs.

ND: not determined.

Number of eggs collected per mouse are expressed as mean \pm SEM.

${ }^{a-c}$ Values with different superscripts within the same column are significantly different $(P<0.001)$.

In untreated mature hyt mice, vaginal cytology showed continuous dioestrus and no eggs were collected (Table 3). Most follicles $>200 \mu \mathrm{m}$ in diameter $(62.3 \%$, 43/69) were degenerative, and few healthy follicles $>400 \mu \mathrm{m}$ in diameter $(1 \pm 0)$ and no corpora lutea were observed in the ovaries of these animals (Fig. 1a). Although treatment with gonadotrophins induced ovulation in mature hyt mice, the number of eggs ovulated was significantly lower than that in normal controls $(P<0.001$, Table 3$)$.

Although there were no significant differences in the number of corpora lutea $<500 \mu \mathrm{m}$ in diameter, corpora lutea in mature hyt mice given gonadotrophins alone were poorly developed and possessed fewer capillaries but many small hollows (Fig. 1b). Significantly lower numbers of corpora lutea $>500 \mu \mathrm{m}$ in diameter and no implantation sites were observed in non-treated female hyt mice given gonadotrophins and mated at 8 weeks of age, regardless of thyroxine treatment after mating. However, mature hyt females given thyroxine before mating had well-developed corpora lutea in the ovaries (Fig. 1c), established pregnancies and delivered offspring (Table 4). Concentrations of progesterone in non-treated female hyt mice were significantly lower than in treated hyt mice and non-treated normal controls (Table 4, $P<0.01$ ).

\section{Discussion}

The results of the present study indicate that ovulation can be induced by gonadotrophin treatment in immature hyt mice. In mature hyt mice, infertility occurs, characterized by a lack of an oestrous cycle, and a response to gonadotrophin treatment followed by a decrease in the number of ovulated eggs, poor corpus luteum formation, lower progesterone concentrations and no implantation. The infertility of mature hyt mice can be reversed by thyroxine treatment even if given before mating. These 

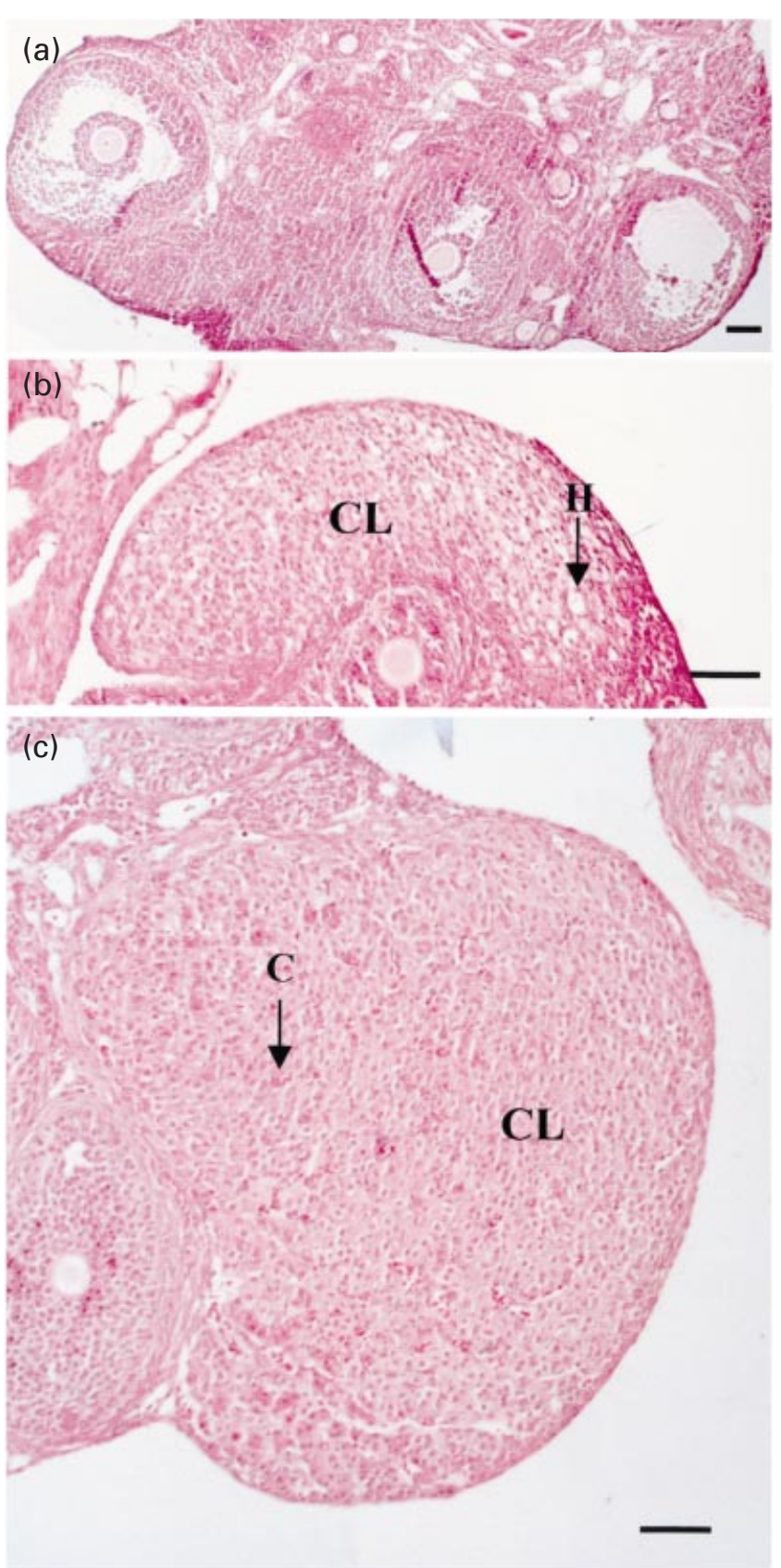

Fig. 1. Ovarian section of an untreated mature hypothyroid (hyt) 61day-old mouse (a) and a corpus luteum $(\mathrm{CL})$ from a mature hyt mouse treated with gonadotrophins (eCG on day 58 and hCG on day 60) alone (b) or with thyroxine alone from day 21 (c). Each female mouse in pro-oestrus or after hCG injection was paired with a male hyt mouse treated with thyroxine. Ovaries were collected 4 days after mating and stained with haematoxylin and eosin. C: capillary; $\mathrm{H}$ : hollow that may be the site of a lipid droplet that has been removed by the alcohol-xylene treatments. Scale bars represent $100 \mu \mathrm{m}$.

findings indicate that infertility in hyt mice is different from that observed in rdw rats, another congenital hypothyroid model. Immature hyt mice responded to gonadotrophin treatment alone and ovulated as many eggs as normal controls. However, immature $r d w$ rats treated with gonadotrophins did not ovulate (Jiang et al., 1999). In immature $r d w$ rats, eCG treatment alone or in combination with eCG and thyroxine, partially and completely revived follicular development, respectively (Jiang et al., 2000a). Indeed, a point mutation that occurs in the thyrotrophin receptor of the hyt mice was not observed in rdw rats (Stein et al., 1994; M. Umezu and J. Y. Jiang, unpublished). In contrast, a novel missense mutation in thyroglobulin that causes hypothyroidism in $r d w$ rats has been reported (Hishinuma et al., 2000). The different gene mutations reported in these two models may result in endocrinological differences, for example in the concentrations of thyroid hormones at different ages, which result in varied infertile characteristics. However, both hyt mice and rdw rats have reduced concentrations of thyroid hormones at both immature and mature stages. hyt mice have congenital hypothyroidism of fetal onset from 15 days after conception and reduced concentrations of thyroid hormones at neonatal, immature and mature stages (Beamer and Cresswell, 1982). Neonatal hyt mice had reduced serum thyroxine ranging from one fifth to one sixth of normal concentrations (Adams et al., 1989). The thyroxine values of hyt mice were $0.34,0.32$ and $0.8 \mu \mathrm{g} \mathrm{dl}{ }^{-1}$ compared with those of normal littermates ( $>6 \mu \mathrm{g} \mathrm{\textrm {dl } ^ { - 1 }}$ ) at 20 days, 5-6 weeks and 6 months of age, respectively (Stein et al., 1989). Reduced concentrations of thyroxine were also found in immature and mature rdw rats (Jiang et al., 1999, 2000b). Therefore, the mechanisms leading to the differences in infertility between immature hyt mice and $r d w$ rats remain unclear and require further investigation.

When female mice are rendered hypothyroid, their ovaries show degenerative changes (Dalton et al., 1945), and the oestrous cycle is altered (Morris et al., 1946). Similarly, rats with hypothyroidism have longer and variable oestrous cycles (Krohn and White, 1950). Hypothyroid cows do not show the usual signs of oestrus (Longcope, 1986). In the present study, untreated mature hyt mice also showed no signs of oestrus and did not ovulate. Histological examination indicated that most follicles were atretic and no corpora lutea were observed. Treatment with gonadotrophins induced ovulation, but the number of ovulated eggs was lower than that in normal controls. These findings were in agreement with the results of previous studies on hypothyroid rats and hens, indicating that hypothyroidism hampered follicular development and ovulation (Longcope, 1986; Jiang et al., 1999, 2000a).

Hypothyroidism has been associated with a wide range of reproductive abnormalities including frequent abortions in many female animals, including women (Maruo et al., 1992; Jiang et al., 2000a). In mature female rats, hypothyroidism apparently does not result in sterility but does interfere with gestation and absorption of the embryos, and subsequently results in reduced litter size (Krohn and White, 1950). Hypothyroidism present at conception interferes with pregnancy and can cause subsequent absorption of the embryos (Longcope, 1986). In adult women, when hypothyroidism is diagnosed during pregnancy, thyroxine 
Table 4. Pregnancy in mature hypothyroid (hyt) mice with or without treatment with gonadotrophins and thyroxine

\begin{tabular}{|c|c|c|c|c|c|c|c|c|}
\hline \multirow[b]{3}{*}{ Females } & \multicolumn{3}{|c|}{ Treatment } & \multirow{3}{*}{$\begin{array}{l}\text { Number of mice } \\
\text { pregnant/tested }\end{array}$} & \multirow{2}{*}{\multicolumn{3}{|c|}{ Number of corpora lutea }} & \multirow{3}{*}{$\begin{array}{c}\text { Progesterone } \\
\text { concentrations } \\
\left(\mathrm{ng} \mathrm{ml}^{-1}\right)\end{array}$} \\
\hline & \multirow{2}{*}{$\begin{array}{l}\text { Gonadotrophins } \\
\text { (eCG and hCG) }\end{array}$} & \multirow{2}{*}{$\begin{array}{c}\text { Thyroxine } \\
\text { before mating* }\end{array}$} & \multirow{2}{*}{$\begin{array}{l}\text { Thyroxine } \\
\text { after mating }\end{array}$} & & & & & \\
\hline & & & & & Total & $\leqslant 500 \mu \mathrm{m}$ & $>500 \mu \mathrm{m}$ & \\
\hline hyt & + & - & - & $0 / 5$ & $6.7 \pm 0.3$ & $6.3 \pm 0.3$ & $0.3 \pm 0.3^{\mathrm{a}}$ & $4.4 \pm 1.7^{c}$ \\
\hline hyt & + & - & + & $0 / 5$ & ND & ND & ND & ND \\
\hline hyt & - & + & - & $5 / 5$ & ND & ND & ND & ND \\
\hline hyt & - & + & + & $5 / 5$ & $9.3 \pm 2.0$ & $6.0 \pm 2.7$ & $3.3 \pm 0.7^{b}$ & $28.4 \pm 6.3^{d}$ \\
\hline Normal & - & - & - & $5 / 5$ & ND & ND & ND & $36.8 \pm 6.6^{d}$ \\
\hline
\end{tabular}

*From 21 days of age until mating.

ND: not determined.

The number of corpora lutea in ovaries $(n=3)$ and concentrations of progesterone are expressed as mean \pm SEM.

Values with different superscripts within the same column are significantly different $\left(\mathrm{ab} P<0.05\right.$; $\left.{ }^{\mathrm{cd}} P<0.01\right)$.

therapy should be commenced promptly to increase the chances of a normal pregnancy. Women requiring thyroid hormone therapy before pregnancy should continue with such therapy throughout pregnancy (Longcope, 1986). The need for thyroxine increases in many women with primary hypothyroidism during pregnancy (Mandel et al., 1990; Tamaki et al., 1990). Hypothyroidism also interferes with the formation and function of corpora lutea, resulting in the failure of normal pregnancy, since the corpus luteum is the primary source of progesterone secretion, which is crucial for maintaining pregnancy to parturition in mammals (Anderson et al., 1999). Luteal-phase defect (LPD), leading to delayed endometrial maturation, may arise as the result of various factors affecting ovarian function. It has been suggested that abnormalities in the follicular phase may be responsible for LPD (Di Zerega and Hodgen, 1981; Soules et al., 1989; Maruo et al., 1992). Although the corpus luteum secretes several species of proteins and sex steroids, the best-characterized manifestation of LPD is a decrease in the concentration of circulating progesterone. Clinically, women with recurrent LPD may present with either infertility or habitual first-trimester abortion (McNeely and Soules, 1988). Experimental findings in vitro indicate that presence of an adequate concentration of thyroid hormone is needed for appropriate FSH-mediated granulosa cell differentiation (luteinization). Since the adequate differentiation of granulosa cells is the pivotal event in formation of the normal corpus luteum, hypothyroxinaemia may be assumed to be one condition responsible for deficient corpus luteum formation (Maruo et al., 1987). Consistent with the possible involvement of thyroid hormones in corpus luteum function, thyroid hormone replacement therapy has been found to be very effective for the treatment of LPD associated with subclinical hypothyroxinaemia. In the present study, both poor corpus luteum formation and insufficient circulating concentrations of progesterone in female hyt mice were improved markedly by thyroxine treatment. Poor corpus luteum formation with lower progesterone concentrations and no pregnancy were observed in mature hyt mice after treatment with gonadotrophins alone. However, thyroxine treatment before mating supported corpus luteum formation and pregnancy, irrespective of treatment with thyroxine after mating. This finding was in agreement with a previous report in women, in which treatment with thyroid hormones in patients with infertility caused by LPD increased the incidence of pregnancy, indicating that a course of thyroid hormone therapy should be administered before more aggressive therapy with chorionic gonadotrophins or Clomid (Naficy and Behjatnia, 1975).

In conclusion, ovulation was induced by gonadotrophin treatment in immature female hyt mice. In mature female hyt mice, infertility occurred that was characterized by a lack of an oestrous cycle, and failure of follicular development, ovulation and pregnancy that could be reversed by thyroxine treatment before mating.

This work was supported by grants from the Program for Promotion of Basic Research Activities for Innovative Biosciences and the 'Research for the Future' Program, the Japan Society for the Promotion of Science (JSPS-RFTF97L00904).

\section{References}

Adams PM, Stein SA, Palnitkar M, Anthony A, Gerrity L and Shanklin DR (1989) Evaluation and characterization of the hypothyroid hyt/hyt mouse I. Somatic and behavioral studies Neuroendocrinology 49 138-143

Amador AG, Parkening TA, Beamer WG, Bartke A and Collins TJ (1986) Testicular LH receptors and circulating hormone levels in three mouse models for inherited diseases ( $\mathrm{Tfm} / \mathrm{y}$, lit/lit and hyt/hyt). Endocrinologia Experimentalis 20 349-358

Anderson LL, Hard DL, Carpenter LS, Awotwi EK, Diekman MA, Trenkle AH and Cho J (1999) Pregnancy, parturition, and lactation in hypophyseal stalk-transected beef heifers Journal of Endocrinology 163 463-475

Ansari MA, de Mello DE, Polk DH and Devaskar UP (1997) Thyrotropinreleasing hormone accelerates fetal mouse lung ultrastructural maturation via stimulation of extra thyroidal pathway Pediatric Research 42 709-714

Ansari MA, de Mello DE and Devaskar UP (2000) Effect of prenatal glucocorticoid on fetal lung ultrastructural maturation in hyt/hyt mice with primary hypothyroidism Biology of the Neonate 77 29-36

Beamer WG and Cresswell LA (1982) Defective thyroid ontogenesis in fetal hypothyroid (hyt/hyt) mice Anatomical Record 202 387-393

Beamer WJ, Eicher EM, Maltais LJ and Southard JL (1981) Inherited primary hypothyroidism in mice Science 212 61-63 
Biesiada E, Adams PM, Shanklin DR, Bloom GS and Stein SA (1996) Biology of the congenitally hypothyroid hyt/hyt mouse Advances in Neuroimmunology 6 309-346

Braw RH and Tsafriri A (1980) Effect of PMSG on follicular atresia in the immature rat ovary Journal of Reproduction and Fertility 59 267-272

Chatot CL, Ziomek CA, Bavister BD, Lewis JL and Torres I (1989) An improved culture medium supports development of random-bred 1-cell mouse embryos in vitro. Journal of Reproduction and Fertility $\mathbf{8 6}$ 679-688

Chubb C and Henry L (1988) The fertility of hypothyroid male mice Journal of Reproduction and Fertility 83 819-823

Chubb C and Nolan C (1985) Animal models of male infertility: mice bearing single-gene mutations that induce infertility Endocrinology 117 338-346

Dalton AJ, Morris HP and Dubnik CS (1945) Changes in organs of female $\mathrm{C}_{3} \mathrm{H}$ mice receiving thiourea Journal of the National Cancer Institute 5 $451-454$

Di Zerega GS and Hodgen GD (1981) Luteal phase dysfunction infertility: a sequel to aberrant folliculogenesis Fertility and Sterility 35 489-499

Hirshfield AN and Midgley AR (1978) Morphometric analysis of follicular development in the rat Biology of Reproduction 19 597-605

Hishinuma A, Furudate S, Oh-Ishi M, Nagakubo N, Namatame T and Ieiri T (2000) A novel missense mutation (G2320R) in thyroglobulin causes hypothyroidism in rdw rats Endocrinology 141 4050-4055

Jiang JY, Miyoshi K, Umezu M and Sato E (1999) Superovulation of immature hypothyroid $r d w$ rats by thyroxine therapy and the development of eggs after in vitro fertilization Journal of Reproduction and Fertility 116 19-24

Jiang JY, Umezu M and Sato E (2000a) Improvement of follicular development rather than gonadotrophin secretion by thyroxine treatment in infertile immature hypothyroid $r d w$ rats Journal of Reproduction and Fertility 119 193-199

Jiang JY, Umezu M and Sato E (2000b) Characteristics of infertility and the improvement of fertility by thyroxine treatment in adult male hypothyroid rdw rats Biology of Reproduction 63 1637-1641

Khan JY, Rajakumar RA, Devaskar UP, Weissfeld LA and Devaskar SU (1999) Effect of primary congenital hypothyroidism upon expression of genes mediating murine brain glucose uptake Pediatric Research 45 $718-725$

Krohn PL and White HC (1950) The effect of hypothyroidism on reproduction in the female albino rat Journal of Endocrinology $\mathbf{6}$ 375-385

Kuroda K (1989) Study on testicular tissue in animals with congenital hormone deficiency Nippon Hinyokika Gakkai Zasshi 80 3-10 (in Japanese)

Longcope C (1986) The male and female reproductive systems. In Werner's The Thyroid: A Fundamental and Clinical Text 5th Edn Eds SH Ingbar and LE Braverman. JB Lippincott Company, Philadelphia

McNeely MJ and Soules MR (1988) The diagnosis of luteal phase deficiency: a critical review Fertility and Sterility 50 1-15

Mandel SJ, Larsen PR, Seely EW and Brent GA (1990) Increased need for thyroxine during pregnancy in women with primary hypothyroidism New England Journal of Medicine 323 91-96

Maruo T, Hayashi M, Matsuo H, Yamamoto T, Okada H and Mochizuki M (1987) The role of thyroid hormone as a biological amplifier of the actions of follicle-stimulating hormone in the functional differentiation of cultured porcine granulosa cells Endocrinology 121 1233-1241

Maruo T, Katayama K, Barnea ER and Mochizuki M (1992) A role for thyroid hormone in the induction of ovulation and corpus luteum function Hormone Research 37 Supplement 1 12-18

Morris HP, Dubnik C and Dalton AJ (1946) Effect of prolonged ingestion of thiourea on mammary glands and the appearance of mammary tumours in adult $\mathrm{C}_{3} \mathrm{H}$ mice Journal of the National Cancer Institute 7 159-169

Naficy $\mathbf{H}$ and Behjatnia $\mathbf{Y}$ (1975) The effect of thyroid extract on luteal phase deficiency Acta Medica Iranica 18 55-60

Sher ES, Xu XM, Adams PM, Craft CM and Stein SA (1998) The effects of thyroid hormone level and action in developing brain: are these targets for the actions of polychlorinated biphenyls and dioxins? Toxicology and Industrial Health 14 121-158

Sole E, Calvo R, Obregon MJ and Meseguer A (1994) Thyroid hormone controls the cell-specific expression of the kidney androgen-regulated protein gene in S3 mouse kidney cells Endocrinology 135 2120-2129

Sole E, Calvo R, Obregon MJ and Meseguer A (1996) Effects of thyroid hormone on the androgenic expression of KAP gene in mouse kidney Molecular and Cellular Endocrinology 119 147-159

Soules MR, Clifton DK, Cohen NL, Bremner WJ and Steiner RA (1989) Luteal phase deficiency: abnormal gonadotrophin and progesterone secretion patterns Journal of Clinical Endocrinology and Metabolism 69 813-820

Stein SA, Shanklin DR, Krulich L, Roth MG, Chubb CM and Adams PM (1989) Evaluation and characterization of the hyt/hyt hypothyroid mouse II. Abnormalities of TSH and the thyroid gland Neuroendocrinology 49 509-519

Stein SA, Oates EL, Hall CR, Grumbles RM, Fernandez LM, Taylor NA Puett D and Jin S (1994) Identification of a point mutation in the thyrotropin receptor of the hyt/hyt hypothyroid mouse Molecular Endocrinology 8 129-138

Tamaki H, Amino N, Takeoka K, Mitsuda N, Miyai K and Tanizawa O (1990) Thyroxine requirement during pregnancy for replacement therapy of hypothyroidism Obstetrics and Gynecology 76 230-233

Umezu M, Kagabu S, Jiang J and Sato E (1998) Evaluation and characterization of congenital hypothyroidism in $r d w$ dwarf rats Laboratory Animal Science 48 496-501

Wakayama T, Whittingham DG and Yanagimachi R (1998) Production of normal offspring from mouse oocytes injected with spermatozoa cryopreserved with or without cryoprotection Journal of Reproduction and Fertility $11211-17$

Received 18 April 2001.

First decision 11 June 2001.

Accepted 24 July 2001. 